Teaching Technique and Activity for the Education of the Gifted Young Scientist

\title{
Investigating Existence of Research Skills in Pre-Service Science Teachers' Lesson Plan Document
}

\author{
S. HARYATI ${ }^{1}$, S. SUKARNO², S. SISWANTO 3 , S. GUMILAR ${ }^{4}$, Ahmad \\ MUHLISIN $^{5}$
}

Received: 08 October 2019 Revise: 31 January 2020 Accepted: 16 February 2020

\begin{abstract}
The article focuses on investigating the existence of research skill in pre-service science teachers' lesson plan. A content analysis was employed as a research method to analyze lesson plan documents made by pre-service science teachers. A number of eighty participants who are college students in department of science education in a state university in Indonesia contributed in creating lesson plan. The documents were then analyzed using Research Skill Development (RSD) frameworks. The findings show that there are three types of lesson plan chosen to be developed: cooperative learning (CL), direct instruction (DI), and guided inquiry (GI). The model of GI lesson plan is the highest proportion among other lesson plan model's crafted by pre-service science teachers. In addition, sixty documents of lesson plan integrate research skill. When these elaborated using RSD frameworks, fifty documents was in prescribed research; ten documents was in bounded research with depicting a comprehensive six facets of RSD frameworks. An implication of this present study indeed is how to create an appropriate strategy in applying the lesson plan model for students in the classroom including gifted students.
\end{abstract}

\section{Keywords:}

research skills, RSD framework, content analysis, pre-service science teacher, lesson plan document

\section{To cite this article:}

Haryati, S., Sukarno, S., Siswanto, S., Gumilar, S., \& Muhlisin, A. (2020) Investigating Existence of Research Skills in Pre-Service Science Teachers' Lesson Plan Document. Journal for the Education of Gifted Young Scientists, 8(1), 183-196. DOI: http://dx.doi.org/10.17478/jegys.630703

\footnotetext{
${ }^{1}$ Faculty of Education and Teacher Training, Universitas Tidar, Indonesia. sriharyati@untidar.ac.id.

${ }^{2}$ Faculty of Education and Teacher Training, Universitas Tidar, Indonesia. sukarno@untidar.ac.id.

${ }^{3}$ Department of Natural Science Education, Universitas Tidar, Indonesia. siswanto@untidar.ac.id.

${ }^{4}$ Department of Physics Education, Institut Pendidikan Indonesia, Indonesia, surya.gumilarr@gmail.com.

${ }^{5}$ Department of Natural Science Education, Universitas Tidar, Indonesia. ahmadmuhlisin@untidar.ac.id.
} 


\section{Introduction}

Research becomes a pivotal part that is inseparable in the world of higher education (Junpeng, 2014; Wannapiroon, 2014) including research of gifted students. Learning that integrates the values of research into learning is to be trends in higher education lately (Junpeng, 2014). This is due to learning-integrated research skills can improve student learning outcomes in depth (Srikoon, 2014) and facilitate students to be able to construct their own knowledge (Wannapiroon, 2014). In other words, the achievement of learning outcomes in the cognitive, affective, and psychomotor domains can be achieved by students by implementing teaching and learning activities that integrate research activities (Sota, 2017). Learning-integrated research skills therefore become crucial to be applied in the classroom, in particular in the world of higher education.

Learning-integrated research skill is a learning activity that facilitates students to carry out scientific stages (through an inquiry activity) in a particular scientific field (Kinkead, 2003). In this context there is a learning system in which it uses authentic learning, problem solving, cooperative learning, direct learning, and inquiry activities based on the philosophy of constructivism learning (Wannapiroon, 2014). Through these activities, students are trained to build their knowledge independently to obtain meaningful teaching and learning activities.

In the context of higher education, many previous research investigated research skill of college students. For instance, the researchers (Ain, Sabir, and Willison, 2018) revealed how research skills were enacted to genders. Findings of this research showed that there were similarities in research skill between male and female in undergraduate students. Another research focused on exploring RSD frameworks to extrapolate students' research skills in a first-year biology practical unit (Torres, 2018). The results showed that students owned the research skills because they were implied through practical activities. In addition, Willison (2016) investigated how research skill of students when the academic curriculum integrated research skill was. In this context, academics indicated that there was an enhancement of teaching process, and feedback for students when the development of research skill was engaged to the teaching and learning process. Despite process of direct learning, online program in master degree provided an opportunity to integrate research skill. Jacobsen et al (2018) implemented an inquiry-based signature pedagogy grounded in the innovative practice of researchbased learning in online course of master of education program; they found that the program situated students owning research-based learning experiences. All these researches portray that the learning process both integrating and not to integrating research skill can be analyzed to recognize students' research skill after taking learning process. 
In line with the research related to research skill, this paper strengthens findings of science education research whether the learning process implies research skill or no to students. In this context, this present study investigates pre-service teachers in representing research skill in lesson plan made. This highlights the level of research skill in the context of students' autonomous and RSD framework. The research question and finding of this research based on content analysis are then discussed.

\section{Research Skills for College Students}

Research skill is commonly introduced to college students through several activities that are underpinned research experiences both in classroom and practical activities (Corwin et al., 2015). There are benefits when research skills are implemented in classroom. One of these is that they can shape and enhance not only a number of basic scientific skills but also promoting acquisition of higher order thinking skills (HOTs) that highlight the basis of critical thinking (Kardash, 2000). Despite supporting HOTs, it is not easy to adjust the learning environment that supports research skills. In other words, there is demanding situation to cultivate, nurture, and develop research skills of students in particular in science education (Torres, 2018). Willison and O'Regan (2007) argued that new comprehending of research skill as both a product and a process of university education need to be conceptualized to provide research experiences for college students. This aims to make continuity in bridging students to learn research skill so that the research skill can be accepted.

How to implement the research skill not only for students doing the research but also for students taking coursework? This question needs specific respond because the existence of research skill should be experienced by whole students in college. Willison and O' Regan (2007) provided a point of view that the word "research" should be conceptualized in a certain term in which it should be integrated in teaching and learning process as formal activity instead of considered as a skill that is trained to students. By viewing the term of research as a skill that is a formal activity of researchers, this can be set as an activity ideally developed and practiced continually through an appropriate environment to create meaningful experience of learning.

One realistic way to implement research skill in context of teaching and learning process is to integrate it in regular activity during semester. By several activities such as comprehending content, and making practices (Willison, 2016); students develop their research skill. Willison (2016) argued that the contemporary international agenda were urged to determine methods and outcomes of explicitly developing research skill carried out by making movement in reforming the curricula agenda to encompass the development of research skill. One of the activities that are linked to reforming curricula agenda is to make an alteration 
lesson plan for educator. We know that a lesson plan in teaching and learning process is a tool for guiding educator to achieve their goal so that the quality of lesson should be made by following the objective of learning process. When students are urged to master the research skill, the lesson plan should be directed and implemented to this way.

\section{The RSD Frameworks}

RSD frameworks are developed by Willison and O'Regan (2007) to assist the educators formulating pedagogies that support student learning the research. This framework arranged systematically to highlight and to facilitate the development of college students in carrying out research. Many skills related to HOTs can be trained by this framework, for instance, problem-solving skill and critical thinking skill, discipline-specific research skill and a capacity of lifelong learning (Ain, 2019; Willison, 2016).

RSD framework is a matrix that consists of six facets of research process in first row and level of research autonomous in along top row. The six facets (i.e. from A to F respectively) (Willison and O'Regan, 2007) are Embark and Clarify, Find and Generate, Evaluate and Reflect, Organize and Manage, Analyze and Synthesize, and Communicate and Apply. Willison and O’ Regan (2007) provide the explanation for each facet that can be seen in table-1.

\section{Table 1.}

The Explanation of Each Facet of Research Process in RSD

\begin{tabular}{ll}
\hline \multicolumn{1}{c}{ Facet } & \multicolumn{1}{c}{ Explanation } \\
\hline A- Embark and Clarify & $\begin{array}{l}\text { Embark on research and clarify the needs for knowledge, } \\
\text { heeding ethical, cultural, and social factors }\end{array}$ \\
\hline B- Find and Generate & $\begin{array}{l}\text { Find information and generate relevant data, using } \\
\text { discipline-appropriate methods }\end{array}$ \\
\hline C- Evaluate and Reflect & $\begin{array}{l}\text { Evaluate information and data and reflect on processes } \\
\text { used }\end{array}$ \\
\hline D-Organize and Manage & $\begin{array}{l}\text { Organize information and manage the processes of } \\
\text { research }\end{array}$ \\
\hline E- Analyze and Synthesize & Analyze information and data, and synthesize new knowledge \\
\hline F- Communicate and Apply & $\begin{array}{l}\text { Communicate and apply new knowledge, conscious of } \\
\text { ethical, cultural and social adaptation and flexibility }\end{array}$ \\
\hline
\end{tabular}

On the other hand, the level of students' research autonomous in along top row encompasses five autonomous level from closed and prescribed to openended research process (Willison and O’Regan, 2007). Prescribed research refers to lowest level in which students are provided a specific direction and modeling while open-ended refers to highest level in which students initiate to conduct research independently. RSD frameworks has been utilized in multiple course as a tool of analysis of research skill (Willison and Buisman-Pijlman, 2016; Willison, Sabir, and Thomas, 2017; Wilmore and Willison, 2016; Ain, Sabir, and Willison, 2019). It has 
also been used as a model for analysis of student learning and thinking, and its six facets have been used in this way in the current paper (Ain, Sabir, and Willison, 2019). In this present study, RSD frameworks are utilized to analyze the existence of research kill in pre-service teachers' lesson plan documents.

\section{Research Question}

This present study is focused on investigating the representation of research skill in pre-service teachers' lesson plan document. We aim to recognize the capacity of pre-service teachers in presenting research skill. Indeed, this also aims to reveal the level of students' research autonomous in carrying out the research that is represented in lesson plan documents. The research question developed in this present study is directed to answer the two aims in above: 1) how are representations or existences of research skill in context of six facets of RSD represented in lesson plan documents? 2) how are representations or existences of students' research autonomous represented in lesson plan documents?

\section{Method}

\section{Research Design}

In order to answer our research question, this present study utilized content analysis, which is one of quantitative non-experimental research designs (Cohen, Manion, and Morrison, 2017). This method is used to analyze the representation of research skill in lesson plan documents made by pre-service teachers. They took a course related to instructional model and strategy in science teaching and learning. During fourteen meetings, they are taught how to make lesson plan in particular all criteria or components that should be existence. They also learned achievement of students' learning outcomes in three domains, namely cognitive, affective, and psychomotor that encompasses learning outcomes of teaching and learning process for $21^{\text {st }}$ century skill. At the end of learning process, they are obligated to make one lesson plan that focuses on one science content in which one pre-service teacher should make one lesson plan. The instructional models utilized in lesson plan were directed to three types of instructional models: cooperative learning (CL), direct instruction (DI), and guided inquiry learning (GI). There is no information of research skill; they just focus on creating lesson plan based on the criteria of lesson plan, learning outcome, and three instructional models.

\section{Participants}

Participants in this present study were eighty college students in department of science education in one state university in Indonesia (i.e. Universitas Tidar) who take course of instructional model and strategy in second year of college. The average age of participants was $\mathrm{M}=19.42(\mathrm{SD}=0.59)$, and the participants consisted of 45 females and 35 males. 


\section{Data Collection}

Data were gathered by collecting firsthand data in form of several lesson plan documents of science pre-service teachers. A task was obligated to pre-service teachers in which they should create a lesson plan for science learning. It then was compiled and analyzed. Each document was written to inform a content knowledge, instructional model including its syntax, and component of lesson plane that elaborated in several aspects that should be conducted both teachers and students in science classroom. The component of lesson plan should contain three components and several key activities that should be done by students in the classroom during the learning process (see table-2). These components refer to science curriculum that is established by Ministry of Education and CultureIndonesia.

\section{Table 2.}

The Component or Criteria of Lesson Plan with the Key Activities

\begin{tabular}{|c|c|}
\hline Component & Key Activities \\
\hline Introduction & $\begin{array}{l}\text { - Apperception: the teachers' activity connecting the content } \\
\text { knowledge that will be learned with previous content that makes a } \\
\text { relationship. } \\
\text { - Motivation: the teachers' activity displaying the problem as a } \\
\text { stimulation to improve students' motivation in learning new } \\
\text { content. }\end{array}$ \\
\hline Core & $\begin{array}{l}\text { Depending on the syntax of instructional model that is utilized by } \\
\text { pre-service teachers, namely cooperative learning (CL), direct } \\
\text { instruction (DI), and guided inquiry (GI). }\end{array}$ \\
\hline Closing & $\begin{array}{l}\text { - Feedback: students' activity to make critique and evaluation to } \\
\text { teaching and learning process in obtaining the content knowledge. } \\
\text { - Confirmation: teachers' activity in underlining the correct } \\
\text { concepts of content knowledge }\end{array}$ \\
\hline
\end{tabular}

\section{Analysis Data}

There were three procedures conducted in the present study. First, all lesson plan documents were counted to assert the number of documents analyzed. RSD framework as an instrument to differ the levels of research process was then utilized to determine the types of research process. Each lesson plan encompassing research skill in RSD framework was coded: type one (1) (i.e. lesson plan contains part or whole six facets of RSD framework), and type two (2) (i.e. lesson plan does not contain a part or whole six facets of RSD frameworks). Second, level of students' research autonomous in RSD framework that has six levels was used to assess the level of students in conducting research. Each indicator that emerged in lesson plan was also coded. Level one (1) means prescribed research; Level two (2) means bounded research; Level three (3) means scaffolded research; Level four (4) means students-initiated research; Level five (5) means open-ended research. Every level of students' autonomous is linked to six facets of research process of RSD. 
Last but the least, the proportion of type of lesson plan and level of students' autonomous were presented to identify the quantity and quality of lesson plan when they are viewed from RSD framework perspectives.

\section{Results}

In this section, we present data in two categories based on RSD frameworks: types lesson plan based on six facets and level of students' autonomous represented in lesson plan documents.

\section{Six Facets of RSD in Lesson Plan Documents}

According to eighty documents analyzed, we divided the documents into three types of lesson plan based on instructional model utilized and chosen by preservice science teachers in presenting core of lesson plan (see table-3).

Table 3.

The Proportion of Lesson Plan Category based on Instructional Model

\begin{tabular}{ccc}
\hline Instructional model & Number & Proportion (\%) \\
\hline Cooperative learning (CL) & 30 & 38 \\
\hline Direct Instruction (DI) & 10 & 12 \\
\hline Guided Inquiry (GI) & 40 & 50 \\
\hline
\end{tabular}

The type of DI lesson plan dominates among others in which it achieve a half of the total number of lesson plan. The second highest proportion is CL lesson plan while the type of DI lesson plan is the lowest proportion. There is no specific reason from pre-service teachers why they decide to use a certain instructional model. It is forecasted that content knowledge that is taken affecting the ways they choose the instructional model to be presented in core of lesson plan. Guided inquiry instructional model indeed is closely used in science classroom so this situation may urge pre-service teachers choose to be implemented in lesson plan.

Using code made in analysis data, we elaborated the data in table 3 to recognize the research process represented in each type of lesson plan whether all types of lesson contain research process or six facets of RSD or no (see table 4). According to table 4, there is no unique data when lesson plan analyzed using six facets of RSD. All documents of GI lesson plan show type one in which they contain a part or whole of six facets of RSD. Indeed, this is rationale because guided inquiry consists of component of research, for example, problems provided to be responded by students. With providing problems, we can predict that the research process of facet-A (Embark and Clarify) is provided to students, for instance. In addition, one third of all documents CL lesson plan depicts a part of six facets of RSD. This means that the syntax of CL instructional model offer an opportunities for students to learn research skill implicitly. The last data show how DI lesson plan does not contain a part of six facets of research process in RSD. This is type 
of conventional instructional model in which it is dominated by teachers' activities instead of providing wide opportunities to students carrying out the research. Rationally this finding shows that the activities centered in students during learning process have a probability in implying the research skill.

\section{Table 4.}

The proportion of type of six facets of RSD represented in lesson plan

\begin{tabular}{cccc}
\hline \multirow{2}{*}{ Type of research process } & \multicolumn{3}{c}{ Type of instructional model } \\
\cline { 2 - 4 } & CL (\%) & DI (\%) & GI (\%) \\
\hline One (contain part or whole six facets) & 33 & 0 & 100 \\
\hline Two (no six facets of RSD presented) & 67 & 100 & 0 \\
\hline
\end{tabular}

For instance, we present a part of sample of lesson plan made by pre-service teacher in which this utilized Guided Inquiry as an instructional model in core activity of lesson plan. In this part, students are directed to carry out several activities that lead to six facets of research skill development (see Apendix-1).

\section{Students' Research Autonomous in Lesson Plan Document}

After positioning the type of research process in lesson plan documents, we shift to elaborate the level of students' research autonomous presented in lesson plan documents (see table 5). The all documents which are categorized as type one (i.e. contain part or whole of six facets of RSD) are again analyzed to explore what the position of students' autonomous research whether it presented highest level (Level five) or just represented the lowest level (Level one).

Table 5.

The Proportion of Students' Research Autonomous Represented in Lesson Plan

\begin{tabular}{|c|c|c|c|c|c|c|}
\hline \multirow{3}{*}{$\begin{array}{l}\text { Level of students' research } \\
\text { autonomous }\end{array}$} & \multicolumn{6}{|c|}{ Type of instructional model } \\
\hline & \multicolumn{2}{|c|}{$\mathbf{C L}$} & \multicolumn{2}{|c|}{ DI } & \multicolumn{2}{|c|}{ GI } \\
\hline & $\mathbf{N}$ & $(\%)$ & $\mathbf{N}$ & $(\%)$ & $\mathbf{N}$ & $(\%)$ \\
\hline Level one (prescribed research) & 10 & 33 & 0 & 0 & 40 & 80 \\
\hline Level two (bounded research ) & 0 & 0 & 0 & 0 & 10 & 20 \\
\hline Level three (scaffolded research) & 0 & 0 & 0 & 0 & 0 & 0 \\
\hline Level four (students-initiated research ) & 0 & 0 & 0 & 0 & 0 & 0 \\
\hline Level five (open-ended research) & 0 & 0 & 0 & 0 & 0 & 0 \\
\hline
\end{tabular}

According to the table 5, we can consider that no all levels of students' research autonomous presented in lesson plan documents. The finest level just reaches level two in which the students' activities are placed in bounded research. It just achieves $20 \%$ of total GI lesson plan provided this level while the others are placed in level one (prescribed research). Interestingly enough that 15 out of 40 GI lesson plan document show three out of six facets in level one: embark and clarify, find and generate, and communicate and apply. This situation is similar to all number of CL documents that present three out of six facets of research process. On the other 
hand, 25 out of 40 GI lesson plan documents depict all facets of RSD in level one. Furthermore, despite providing 10 GI lesson plan documents in level two of students' research autonomous, these documents represented all facets of research skill in level two. In other words, all these documents provide a comprehensive six facets of RSD in bounded research.

\section{Discussion and Conclusion}

This present study investigated representation or existence of research skill in lesson plan documents made by pre-service teachers. In context of research process that refers to six facets of RSD, there were two type documents in which type one contains a part or whole of facets of RSD, and type two in which it did not contain facets of RSD. The type documents infusing facets of RSD were using CL and GI as instructional model. In line with the argumentation of Willison (2012) that research skill can be brought through teaching together in learning environment. Clearly, CL and GI lesson plan provide a trajectory for students to work collaborative and this situation leads to cultivation of research skill in the classroom activity. In addition, CL and GI lesson plan easily integrate research skill through problems planned to be solved by students in the early stage of lesson plan.

In term of students' research autonomous, this present study depicts that the quality of lesson plan made by pre-service teachers just achieve level two or bounded research. This was reached by GI lesson plan model; this is too rationale because in guided inquiry students are engaged in investigating the science concepts through guidance made by teachers (Gumilar, S., 2019; Siswanto, et al, 2019; Abdurrahman, A., 2019). If we consider the criteria established by Willison and O'Regan (2007) in RSD framework, it seems that the bounded research emphasize limited direction from educators to assist students conducting the research. In this context, students embark to do experiment independently with provided a little clue by educators. In this context, interestingly enough, all documents show six facets of RSD from facet-A to facet-F. This means the preservice teachers have capability in planning to train research skill to students. This capability indeed affect to skill in evaluating research skill because when an educator has a capacity in teaching explicitly research skill, she/he can assess well these skill (Nightingale, 2009). On the other hand, there is a limited capability in planning to train research skill although pre-service teachers choose to take GI instructional model in creating lesson plan. This situation can be seen in which they just construct a model of GI lesson plan with emphasizing prescribed research. In the other words, they construct highly structured direction and modeling from educator in prompting students' research skill (Willison and O’Regan, 2007). 
More importantly, in the context of science students in the classroom, the quality of skill to make lesson plan presented in students' research autonomous is very important because pre-service teacher will be real teacher in the future. They will face diverse types of students from incapable to gifted students. The differentiation of type of students in the classroom will urge the teacher arrange lesson plan model differently. They will adjust how they train research skill to incapable students and this situation will be influenced the skill of making and integrating research skill in lesson plan model. For example, data showed that preservice teachers' research skill only achieve bounded research; this will not emerge the problems when they train research skill to incapable students in science classroom because they have to embark from low level. On the other hand, the problems will be appeared when pre-service teachers' research skill was low but they should teach gifted students. The gifted student's in science classroom tends to have critical analysis and a particularly high ability to direct their own learning (Neber and Schommer-Aikins, 2002) in science learning process. Therefore, in the context of students' research autonomous, pre-service teachers should master the research skill from prescribed research to open-ended research (Abdulfattah and Supahar, 2019) and can integrate to their lesson plans. These aim to provide an opportunity by creating learning environments which enable gifted students to take decisions about the content and processes of learning themselves (Heller, 1999; Hoekman et al., 1999; Neber and Schommer-Aikins, 2002).

The findings of the critical content analysis finally have a number of pedagogical implications. Contextually, a critical study exhibits research skill represented in lesson plan documents which have similar roles to other studies dealing with research skill. Methodologically, other perspectives analyzing lesson plan documents should be considered by future research for widening research on document analysis for revealing other dimensions of research skill in science education or other domain in education. Then, research studies investigating preservice teachers' perspectives in implementing of lesson plan made should also be conducted.

\section{Recommendations}

The findings of this present study show how college students presented the research skill in their lesson plan made. More importantly, the ability of implementing the lesson plan of college students should be considered directly in the learning process in the classroom. This situation indeed can be an interesting research in advance in which we can investigate what going on in real situation when college students train research skill to their students. By using micro ethnography research, we can analyze several representations both teachers and students in teaching and learning process of research skill. 


\section{Acknowledgement}

The authors would like to acknowledge the support by Universitas Tidar Grant. Gratitude is also extended to all the college students who were involved in this research. Without their cooperation and support, this research would not have been possible.

\section{Biodata of the Author}

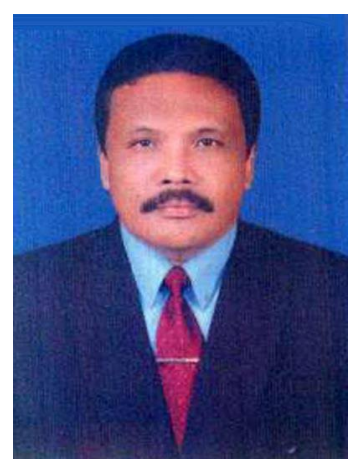

Prof. Dr. Sukarno, M.Si, The Dean of the Faculty of education and teachers training, Universitas Tidar, Indonesia. Universitas Tidar is one of the state university in Indonesia. Professor in the field of education who is engaged in research in the field of higher order thinking skills, research-based learning, and instilling character values. Currently, conducting research on research-based learning design to construct higher-order thinking skills and 21 st century characters. Besides being active in research activities, he is also active in fostering teachers in Central Java Province to improve teaching skills.

Affiliation: Faculty of education and teachers training, Universitas Tidar, Magelang, Indonesia. E-mail: sukarno@untidar.ac.id

ORCID ID: orcid.org/0000-0002-5369-4240

SCOPUS ID: -

WoS ResearcherID : -

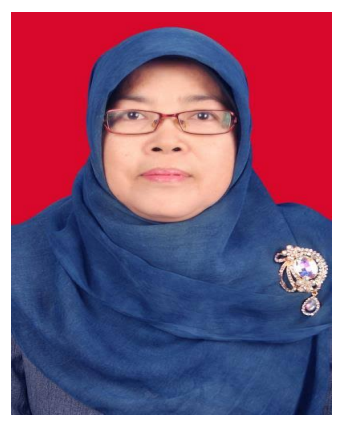

Dr. A Sri Haryanti, M. Pd was born in Klaten, Central Java, Indonesia. Doctor in the field of educational psychology. Currently, actively conducting research on higher-order thinking skills. In addition, she is also active in conducting research in the field of character education. She is the head of the library management unit at Tidar University. She is the senior lecturer in Faculty of education and teachers training, Universitas Tidar, Indonesia. In addition, his research interests are also in the area of learning design. The research project being undertaken is designing research-based learning to be applied at Universitas Tidar.

Affiliation: Faculty of education and teachers training, Universitas Tidar, Magelang, Indonesia. E-mail: sriharyati@untidar.ac.id

ORCID ID: orcid.org/0000-0002-6210-9963

SCOPUS ID: -

WoS ResearcherID : -

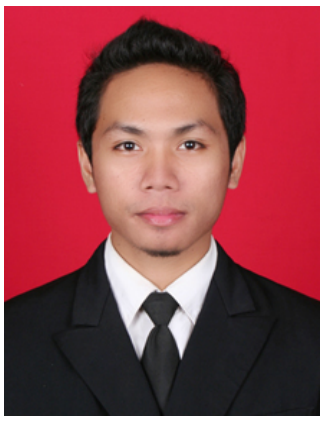

Siswanto, M. Pd, Junior lecturer at Natural Science Education Department of Universitas Tidar. Research interests in the field of higher order thinking skills, research skills, inquiry, and the development of learning designs. Currently conducting research studies on the development of reading activities in science learning. 
Affiliation: Department of Natural Science Education, Universitas Tidar, Magelang, Indonesia. E-mail: siswanto@untidar.ac.id ORCID ID: 0000-00022382-637X SCOPUS ID: 57201668082 WoS ResearcherID : -

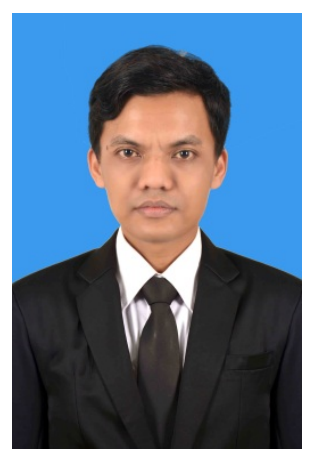

Surya Gumilar, M. Pd, Junior lecturer at Physics Education Department in Institut Pendidikan Indonesa, West Java. He has research interests in the field of critical thinking, research skills, and inquiry laboratory. Affiliation: Department of Physics Education, Institute Pendidikan Indonesia, Garut, West Java.

E-mail: surya.gumilarr@gmail.com

ORCID ID: orchid.org/0000-0001-5699-484X

SCOPUS ID: 57201667822

\section{WoS ResearcherID : -}

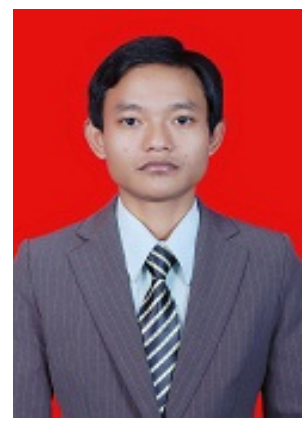

Dr. Ahmad Muhlisin, M. Pd., is a Doktorate of Biology Education. He was born in Grobogan, Central Java, Indonesia. He is a lecture in Natural Science Education in Universitas Tidar. His research focuses on biology education, learning innovation, $21^{\text {st }}$ century learning model, science teaching, critical thinking, metacognition, problem solving, and retention.

Affiliation: Universitas Tidar, Magelang, Central Java, Indonesia E-mail: ahmadmuhlisin@untidar.ac.id

ORCID ID: 0000-0001-9434-0652 SCOPUS ID:

57191473660 WoS ResearcherID : -

\section{References}

Abdulfattah, A., \& Supahar, S. (2019). The Development of Problem-Based Learning Test Instruments for the High School Physics Problem Solving Skills. Journal for the Education of Gifted Young Scientists, 7(4), 1037-1053.

Abdurrahman, A., Nurulsari, N., Maulina, H., \& Ariyani, F. (2019). Design and Validation of Inquiry-based STEM Learning Strategy as a Powerful Alternative Solution to Facilitate Gift Students Facing 21st Century Challenging. Journal for the Education of Gifted Young Scientists, 7(1), 33-56.

Ain, C. T., Sabir, F., \& Willison, J. (2019). Research skills that men and women developed at university and then used in workplaces. Studies in Higher Education, 44(12), 2346-2358.

Cohen, L., Manion, L., and Morrison, K. (2017). Research methods in education ( $7^{\text {th }}$ ed., pp. 3130). London: Routledge Falmer.

Corwin, L. A., Runyon, C., Robinson, A., \& Dolan, E. L. (2015). The laboratory course assessment survey: a tool to measure three dimensions of research-course design. CBE_Life Sciences Education, 14(4), ar37.

Gumilar, S., Ismail, A., Budiman, D. M., \& Siswanto, S. (2019). Inquiry instructional model infused blended experiment: helping students enhance critical thinking skills. Journal of Physics: Conference Series, vol. 1157, no. 3, pp. 032009. IOP Publishing. 
Heller, K. A. (1999). Individual (learning and motivational) needs versus instructional conditions of gifted education. High Ability Studies, 10(1), 9-21.

Hoekman, K., McCormick, J., \& Gross, M. U. M. (1999). The optimal context for gifted students: A preliminary exploration of motivational and affective considerations. Gifted Child Quarterly, 43, 170-193.

Jacobsen, M., McDermott, M., Brown, B., Eaton, S. E., \& Simmons, M. (2018). Graduate students' research-based learning experiences in an online Master of Education program. Journal of University Teaching \& Learning Practice, 15(4), 4.

Junpeng, P., \& Tungkasamit, A. (2014). The continuing professional development of the assessment through research-based learning in higher education of Thailand. ProcediaSocial and Behavioral Sciences, 143, 737-742.

Kardash, C. (2000). Evaluation of an undergraduate research experience: Perceptions of undergraduate interns and their faculty mentors, Journal of Educational Psychology, vol. 92, no. 1, pp. 191-201.

Kinkead, J. (2003). Learning through inquiry: An overview of undergraduate research. New Directions for Teaching and Learning, (93), 5-18.

Neber, H., \& Schommer-Aikins, M. (2002). Self-regulated science learning with highly gifted students: The role of cognitive, motivational, epistemological, and environmental variables. High Ability Studies, 13(1), 59-74.

Nightingale, P. (2009). Making research skill development explicit: Final (summative) report, Retrieved 27 September, 2019, from http://www.adelaide.edu.au/clpd/rsd.

Siswanto, Yusiran, Gumilar, S., Hartono, Subali, B., Muhlisin, A., Juliyanto, E., Trisnowati, E \& Farikah. (2019). Enhancing students' cognitive ability by implanting argumentation activity on inquiry lab. Journal of Physics: Conference Series, vol. 1280, no. 5, pp. 052003. IOP Publishing

Sota, C., \& Peltzer, K. (2017). The Effectiveness of Research Based Learning among Master degree Student for Health Promotion and Preventable Disease, Faculty of Public Health, Khon Kaen University, Thailand. Procedia-Social and Behavioral Sciences, 237, 1359-1365.

Srikoon, S., Bunterm, T., Samranjai, J., \& Wattanathorn, J. (2014). Research synthesis of research-based learning for education in Thailand. Procedia-Social and Behavioral Sciences, 116, 913-917.

Torres, L. (2018). Research Skills in the First-Year Biology Practical-Are They There?. Journal of University Teaching and Learning Practice, 15(4), 3.

Wannapiroon, P. (2014). Development of research-based blended learning model to enhance graduate students' research competency and critical thinking skills. ProcediaSocial and Behavioral Sciences, 136, 486-490.

Willison, J., \& Buisman-Pijlman, F. (2016). PhD prepared: research skill development across the undergraduate years. International Journal of Researcher Development 7 (1): 63-83.

Willison, J., Sabir, F., \& Thomas, J. (2017). Shifting Dimensions of Autonomy in Students" Research and Employment. Higher Education Research \& Development, 36(2), 430-43.

Willison, J., \& O'Regan, K. (2007). 'Commonly known, commonly not known, totally unknown: a framework for Students becoming researchers', Higher Education Research \& Development, vol. 26, no. 4, pp. 393-409. 
Wilmore, M., and J. Willison. (2016). Graduates Attitudes to Research Skill Development in Undergraduate Media Education. Asia Pacific Media Educator, 26(1), 113-28.

\section{Apendix-1.}

Sample of Part of Lesson Plan Made by Pre-service Science Teachers

ID Number : 1810303066

\section{LESSON PLAN}

$\begin{array}{ll}\text { School Name } & : \\ \text { Subject } & : \text { Natural Science } \\ \text { Term } & : \text { Even/year } 3 \text { of Junior High school } \\ \text { Topic } & : \text { Conventional Biotechnology } \\ \text { Duration } & : 90 \text { minutes }\end{array}$

F. Students' and Teachers' Activities

\begin{tabular}{|c|c|c|c|}
\hline $\begin{array}{l}\text { Syntax of } \\
\text { learning } \\
\text { process }\end{array}$ & Students' and teachers' Activities & $\begin{array}{l}\text { Duration } \\
\text { (minutes) }\end{array}$ & $\begin{array}{l}\text { Component of Six } \\
\text { facets of RSD }\end{array}$ \\
\hline Introduction & $\begin{array}{l}\text { - Greeting by students } \\
\text { - Students propose an answer of initial } \\
\text { teachers' question about biotechnology. } \\
\text { - Teacher motivate students by presenting a } \\
\text { video of making a tape (i.e. one type of } \\
\text { local food made by cassava that involves a } \\
\text { fermentation process) } \\
\text { - Students listen an explanation of } \\
\text { biotechnology } \\
\text { - Students write the aims and benefits } \\
\text { studying biotechnology }\end{array}$ & $\begin{array}{l}4 \\
5\end{array}$ & Embark and Clarify \\
\hline Core & $\begin{array}{l}\text { - Students work collaboratively to } \\
\text { understand students' work sheet } \\
\text { - Students consider directly a fermented } \\
\text { product (i.e. tape) } \\
\text { - Students investigate problems of fermented } \\
\text { product (i.e. Tape) } \\
\text { - Students identify a problem that is suitable } \\
\text { - } \quad \text { Sith students' work sheet } \\
\text { - Science textbook) } \\
\text { - Students propose hypothesis about } \\
\text { problem provided. } \\
\text { - Students conduct experiment using lab } \\
\text { apparatus through a guidance of teacher } \\
\text { Students recap and infer the result of the } \\
\text { experiment process }\end{array}$ & $\begin{array}{l}5 \\
5 \\
5 \\
4 \\
5 \\
5 \\
20\end{array}$ & $\begin{array}{l}\text { Organize and manage } \\
\text { Analyze and synthesize- } \\
\text { find and generate } \\
\text { Evaluate and reflect }\end{array}$ \\
\hline Closing & $\begin{array}{l}\text { - Students communicate the result of } \\
\text { experiment } \\
\text { - Students listen feedbacks provided by } \\
\text { teacher }\end{array}$ & $\begin{array}{l}5 \\
5\end{array}$ & $\begin{array}{l}\text { Communicate and } \\
\text { apply }\end{array}$ \\
\hline
\end{tabular}

